Supporting Information for

\title{
Positive Feedback Mechanism to Increase the Charging Voltage of $\mathrm{Li}-\mathrm{O}_{2}$ Batteries
}

Yoko Hase, ${ }^{*}, \dagger$ Takeshi Uyama, ${ }^{\dagger}$ Kiho Nishioka, ${ }^{\ddagger}$ Juntaro Seki, ${ }^{\dagger}$ Kota Morimoto, ${ }^{\star}$ Nobuhiro Ogihara, ${ }^{\dagger}$ Yoshiharu Mukouyama, ${ }^{\perp}+$ and Shuji Nakanishi $*,+, \S$

${ }^{\dagger}$ Toyota Central R\&D Labs., Inc., 41-1 Yokomichi, Nagakute, Aichi, 480-1192, Japan

$¥$ Research Center for Solar Energy Chemistry, Graduate School of Engineering Science, Osaka University, Toyonaka, Osaka 560-8531, Japan

$\S$ Innovative Catalysis Science Division, Institute for Open and Transdisciplinary Research Initiatives (ICS-OTRI), Osaka University, Suita, Osaka 565-0871, Japan

${ }^{\perp}$ Division of Science, College of Science and Engineering, Tokyo Denki University, Hatoyama, Saitama 350-0394, Japan

*Address correspondence to: y-hase@mosk.tytlabs.co.jp (Y.H); nakanishi@chem.es.osaka-u.ac.jp (S.N) 


\section{Supporting Figures and Tables}
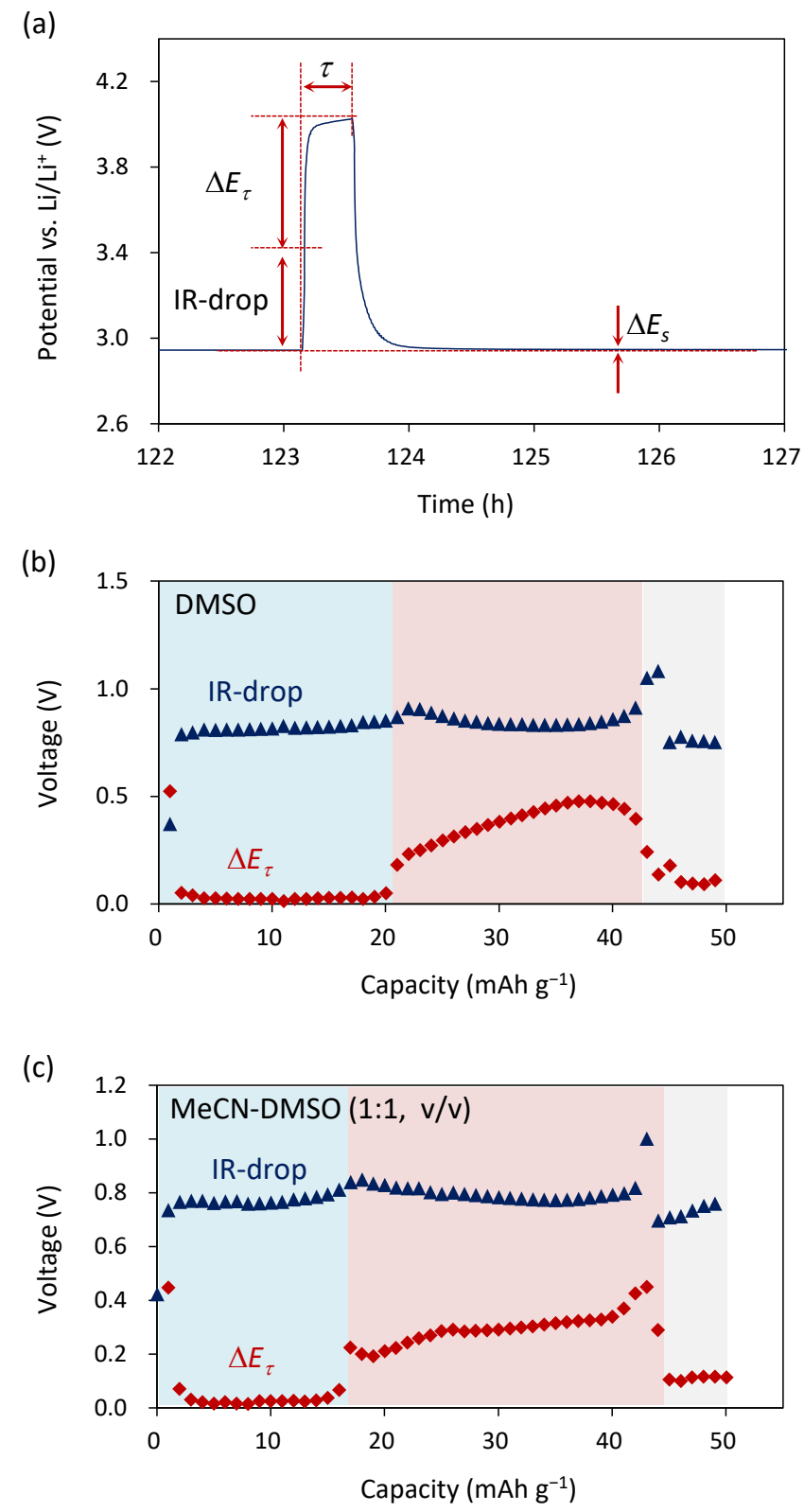

Figure S1. (a) The typical cell voltage profile obtained from the GITT measurement. (b, c) Plot of IR-drop (blue triangles) and $\Delta E_{\tau}$, (red diamonds) for Figure 2a and Figure $2 \mathrm{~b}$, respectively. The IR-drop was estimated from the amount of increase in cell voltage for 30 seconds after applying the current for each step. 

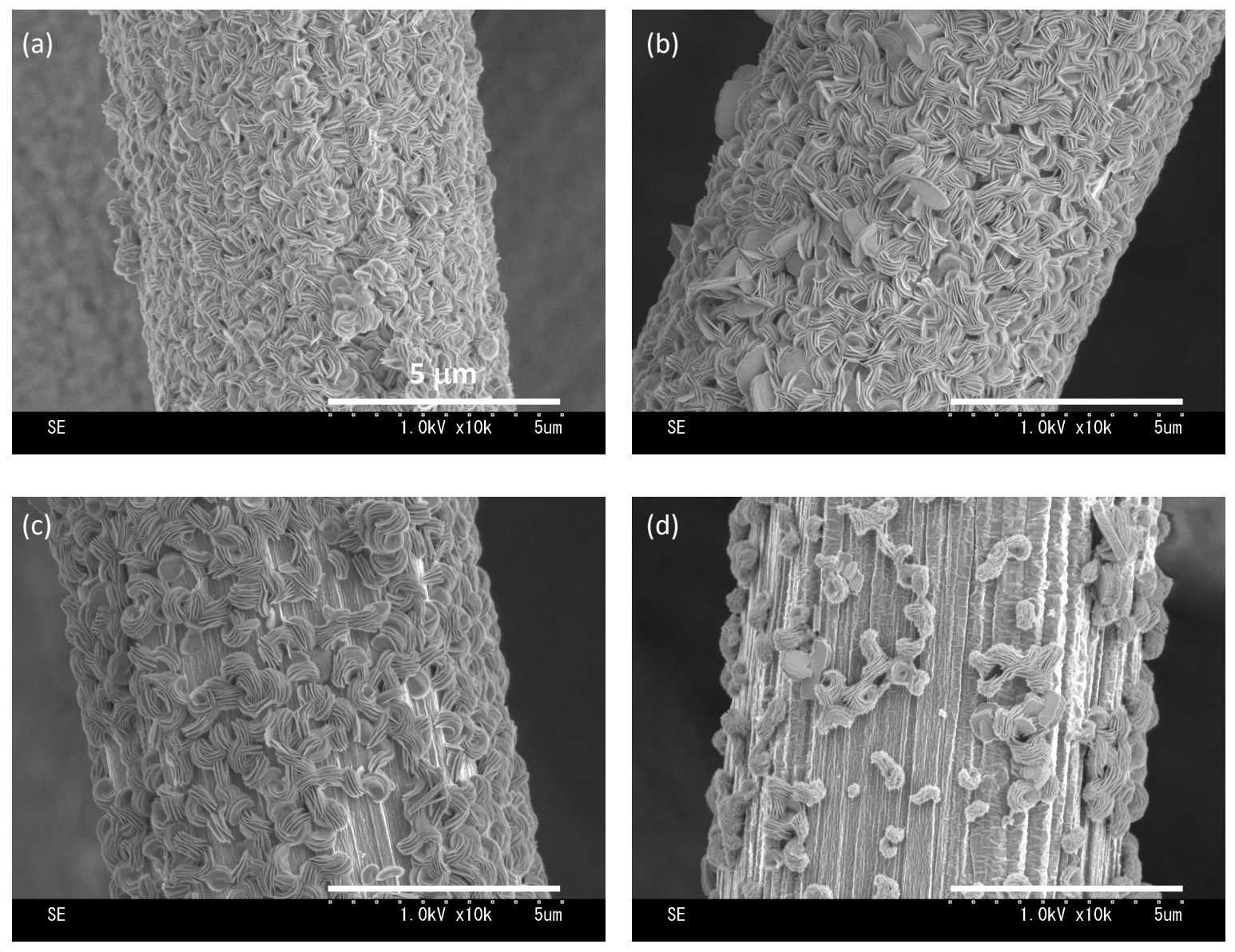

Figure S2. SEM images of cathodes obtained after discharge (a) and the step I (b, c), and at the middle of step II (d) in the $\mathrm{Li}-\mathrm{O}_{2}$ batteries employing the MeCN-DMSO electrolyte. The images of (a), (b), and (d) are same as (ii), (iii), and (iv) shown in Fig. 3, respectively. The image in (c) was obtained at a different position from the image (b) of the same sample. All scale bars, $5 \mu \mathrm{m}$. 

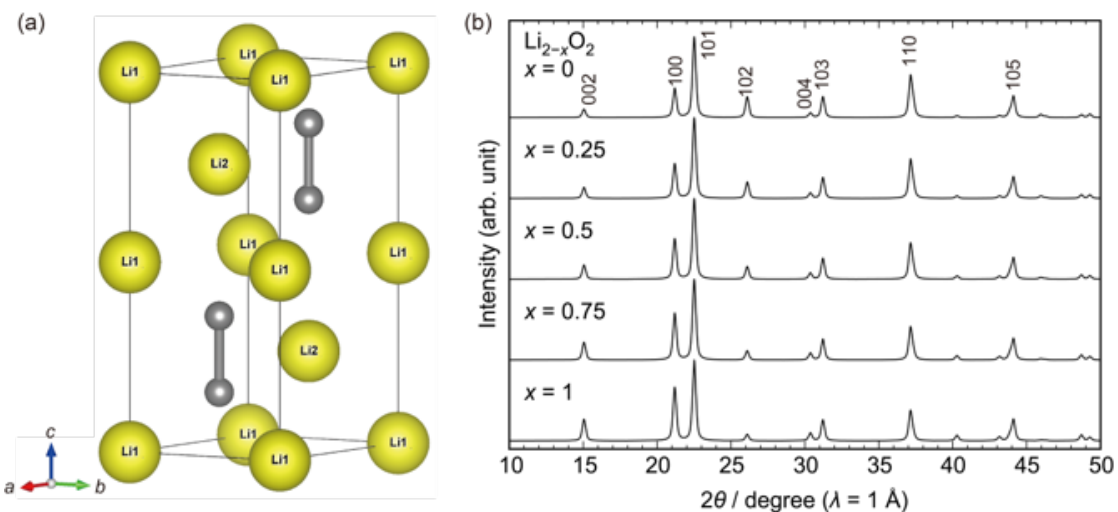

Figure S3. (a) Crystal structure of $\mathrm{Li}_{2} \mathrm{O}_{2}$ and (b) calculated XRD patterns for $\mathrm{Li}_{2-x} \mathrm{O}_{2}$ with $x=0$, $0.25,0.5,0.75$, and $1 . \mathrm{Li}_{2} \mathrm{O}_{2}$ and its Li-deficient phase, $\mathrm{Li}_{2-x} \mathrm{O}_{2}$, adopt the $P 6_{3} / m m c$ space group, in which Li1 and Li2 occupy 2a and 2c Wyckoff position sites, respectively. The calculated XRD was simulated in the assumption of the deficiency of Li1. In (a), gray spheres show O, whereas yellow spheres show Li. In (b), the miller indices are also shown.

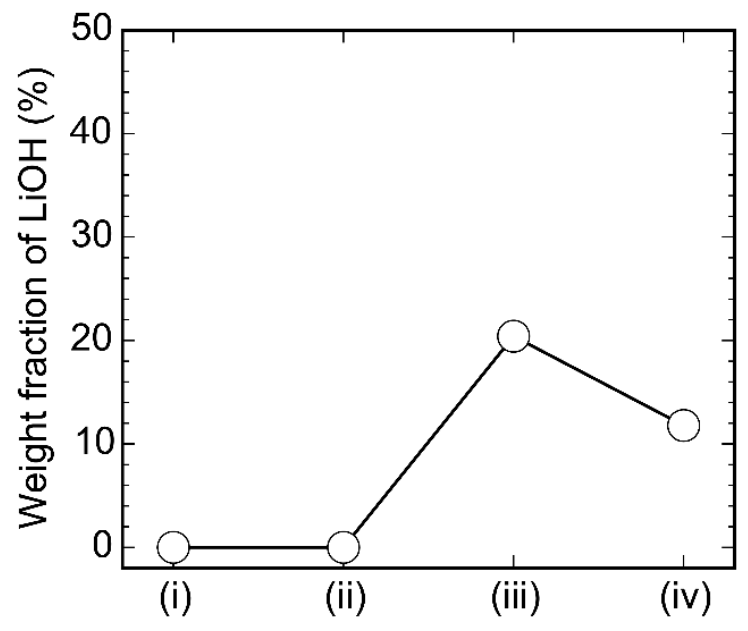

Figure S4. Weight fraction of $\mathrm{LiOH}$ in the sample (i) - (iv) estimated from Rietveld analysis in Figure 4 and Table S2. 
(a)

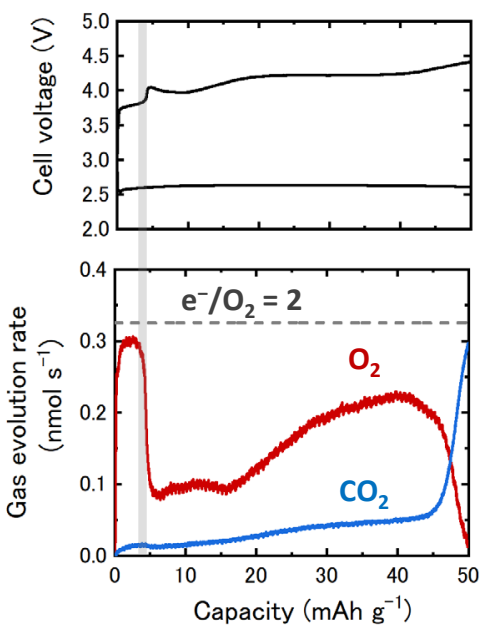

(b)

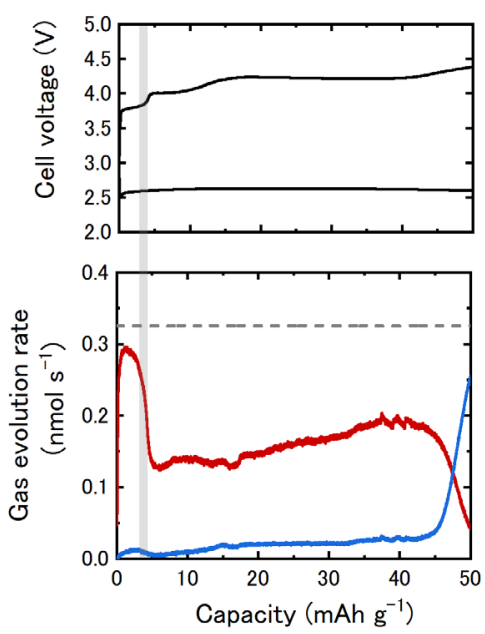

(c)

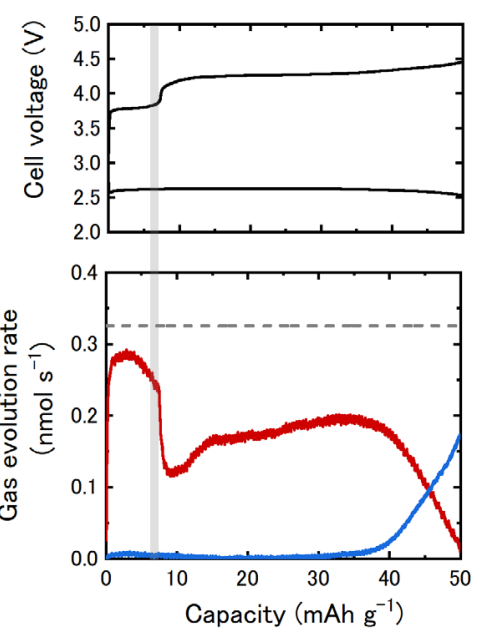

Figure S5. Galvanostatic discharge and charge curves (above) and DEMS profile for three replicate trials (below). The $\mathrm{Li}^{-\mathrm{O}_{2}}$ battery employing $0.5 \mathrm{M} \mathrm{LiTFSI/DMSO}$ as an electrolyte was used for the measurement. The applied current densities were $0.2 \mathrm{~mA} \mathrm{~cm}^{-1}$ and $0.02 \mathrm{~mA} \mathrm{~cm}^{-1}$ for discharge and charge, respectively. $\mathrm{O}_{2}$ (red) and $\mathrm{CO}_{2}$ gases evolution (blue) released from the cell during the charging process after the first discharge, and the theoretical $\mathrm{O}_{2}$ evolution rates $\left(\mathrm{e}^{-} / \mathrm{O}_{2}=2\right.$, gray dashed lines) are depicted in the same figures. 
(a)

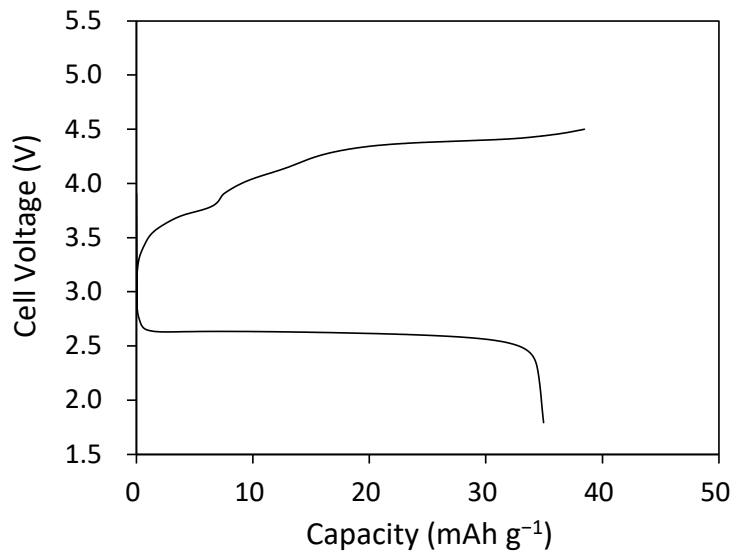

(b)

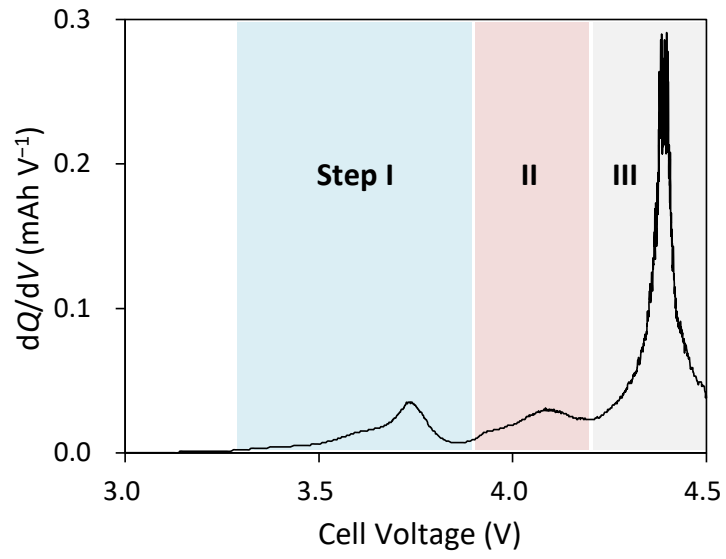

Figure S6. (a) Galvanostatic discharge and charge curves of $\mathrm{Li}-\mathrm{O}_{2}$ batteries employing $0.5 \mathrm{M}$ LiTFSI/DMSO as an electrolyte with a conventional-type cell. The applied current densities were $0.2 \mathrm{~mA} \mathrm{~cm}^{-1}$ and $0.02 \mathrm{~mA} \mathrm{~cm}^{-1}$ for discharge and charge, respectively. (b) Differential capacity $\mathrm{d} Q / \mathrm{d} V$ plot obtained from (a). 


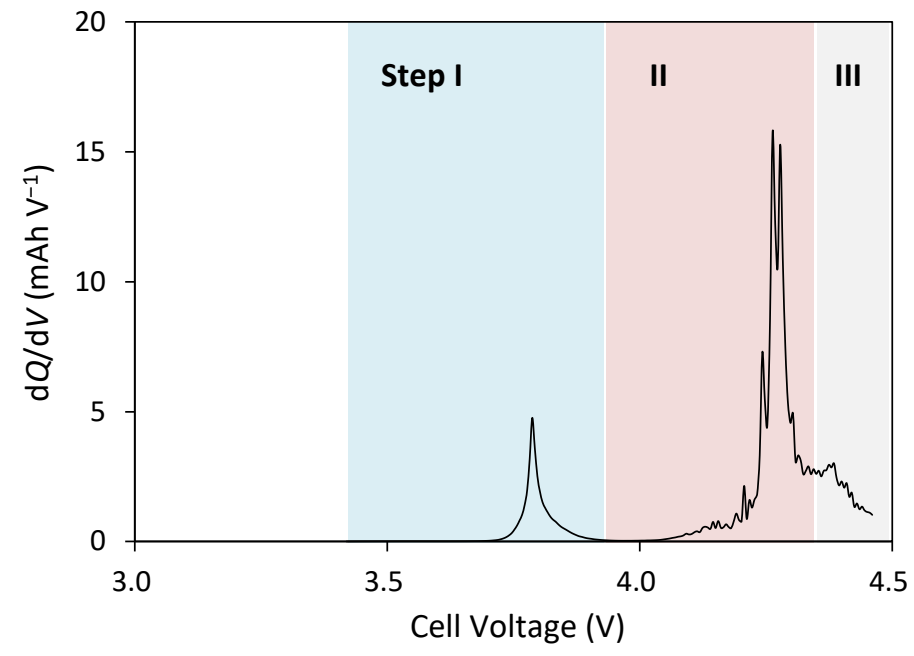

Figure S7. Differential capacity $\mathrm{d} Q / \mathrm{d} V$ plot of $\mathrm{Li}-\mathrm{O}_{2}$ batteries employing the DMSO electrolyte obtained from DEMS measurement shown in Figure S5c. 
(a)

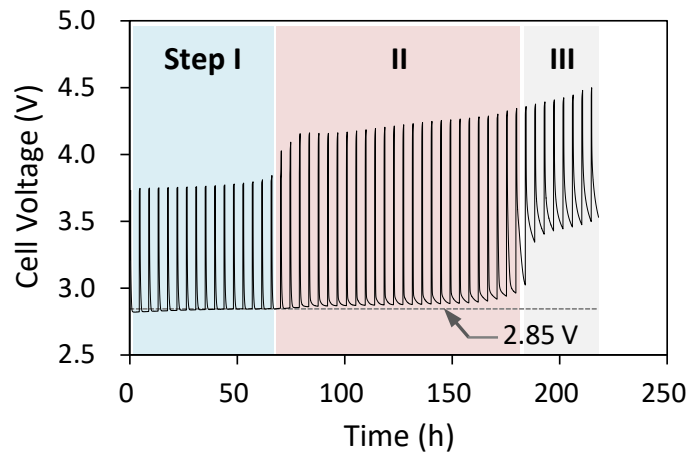

(c)

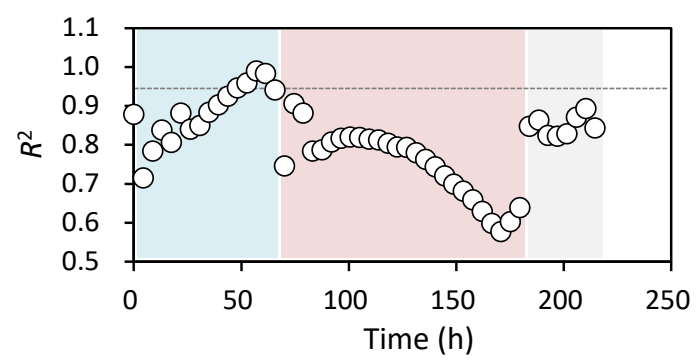

(b)

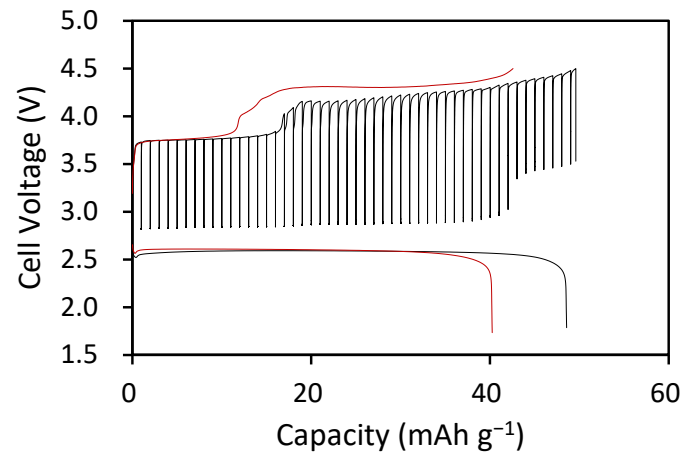

(d)

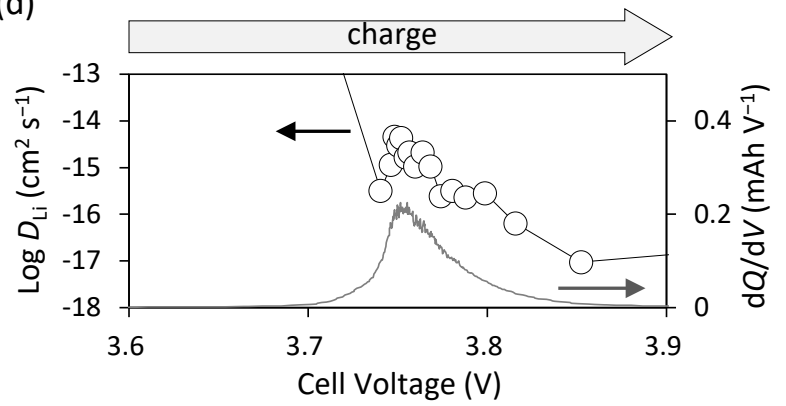

Figure S8. Analysis of $\mathrm{Li}-\mathrm{O}_{2}$ batteries on charging under galvanostatic condition. The analyses were performed using a cell which was attached to an Ar-filled cylinder after discharging under $\mathrm{O}_{2}$ with the electrolyte of $0.5 \mathrm{M} \mathrm{LiTFSI/DMSO}$. The applied current densities were $0.2 \mathrm{~mA} \mathrm{~cm} \mathrm{~cm}^{-1}$ and $0.02 \mathrm{~mA} \mathrm{~cm}^{-1}$ for discharge and charge, respectively. (a) Time course of the cell voltage in GITT measurement of $\mathrm{Li}-\mathrm{O}_{2}$ batteries. (b) Galvanostatic discharge and charge curves (red) and cell voltages on charging vs. capacity obtained by GITT measurements (black). (c) Plot of the squared correlation coefficient, $R^{2}$, calculated from the change of cell voltage on charge for each step of GITT vs. the square root of time $\left(t^{1 / 2}\right)$. (d) Plots of $\mathrm{Li}^{+}$diffusion coefficients $\left(D_{\mathrm{Li}}\right)$ obtained by GITT measurements (a) and $\mathrm{d} Q / \mathrm{d} V$ values vs. Cell Voltage for charging in (b) in step I. 


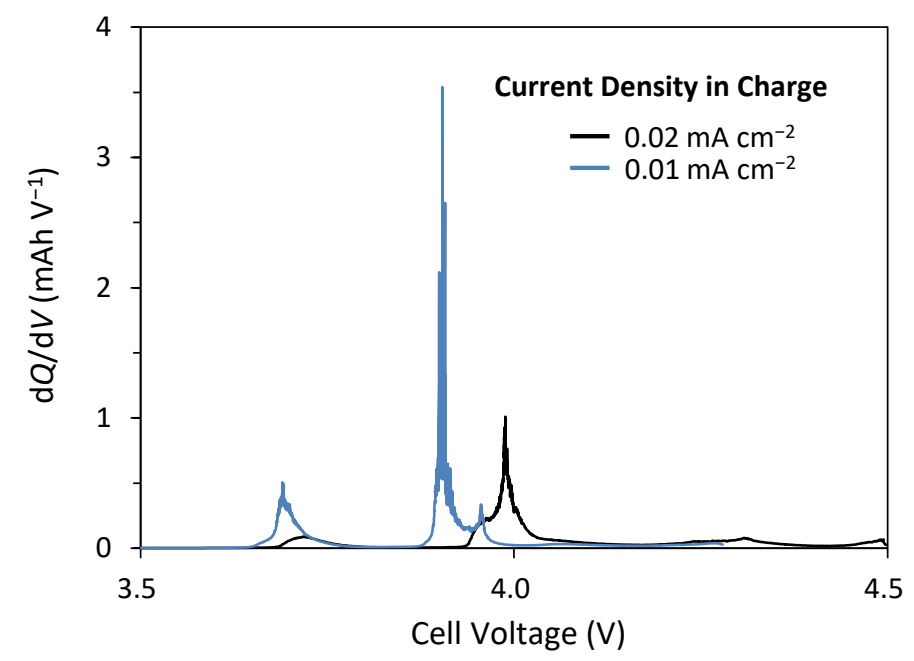

Figure S9. Differential capacity $\mathrm{d} Q / \mathrm{d} V$ plot of $\mathrm{Li}-\mathrm{O}_{2}$ batteries employing $\mathrm{MeCN}-\mathrm{DMSO}(1: 1, \mathrm{v} / \mathrm{v})$ of electrolyte obtained from (Figure 5b). The applied current densities were $0.2 \mathrm{~mA} \mathrm{~cm}{ }^{-2}$ for discharging, and 0.02 (black) and $0.01 \mathrm{~mA} \mathrm{~cm}^{-2}$ for charging (blue), respectively. 
(a) DMSO

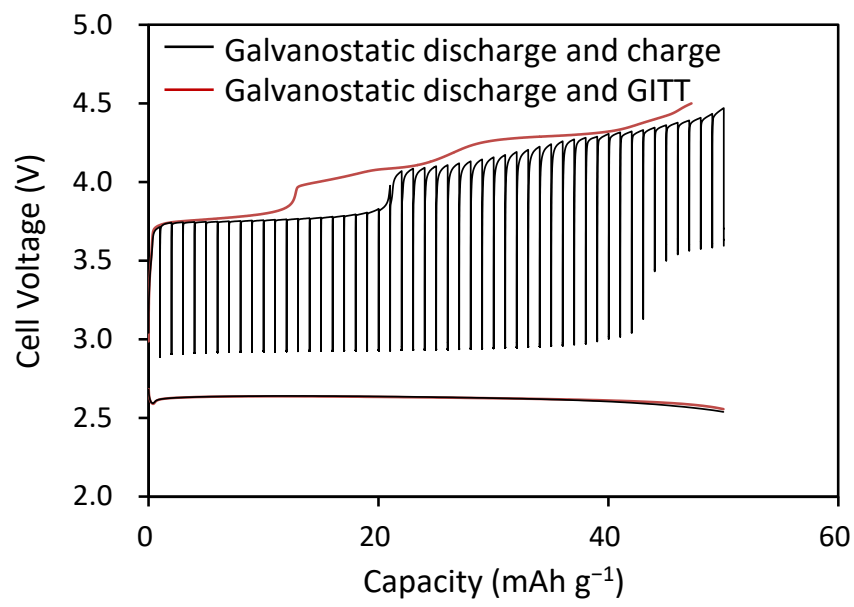

(b)

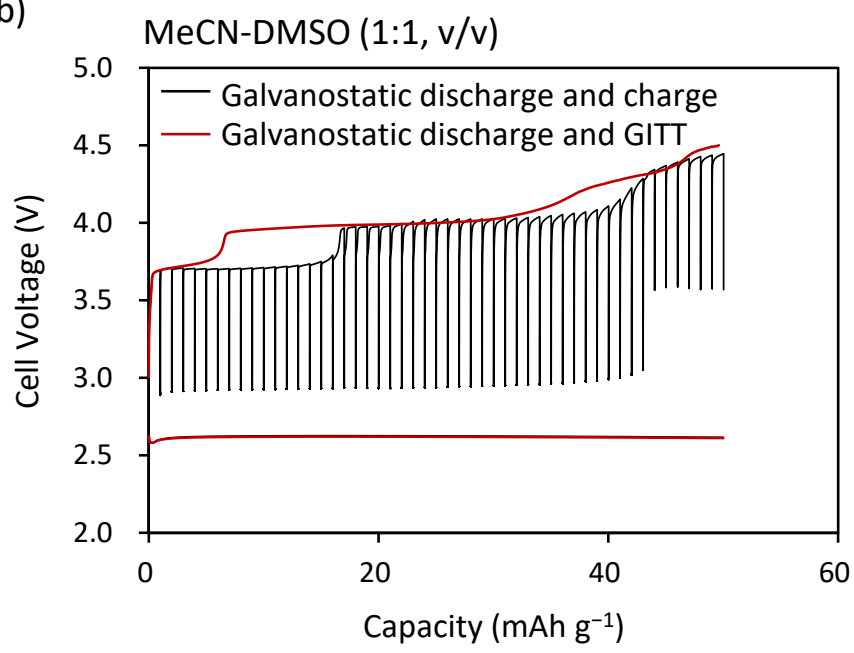

Figure S10. Galvanostatic discharge and charge curves (red) and cell voltages on charging vs. capacity obtained by GITT measurements after galvanostatic discharging (black). The applied current densities were $0.2 \mathrm{~mA} \mathrm{~cm}^{-1}$ and $0.02 \mathrm{~mA} \mathrm{~cm}^{-1}$ for discharge and charge, respectively. 


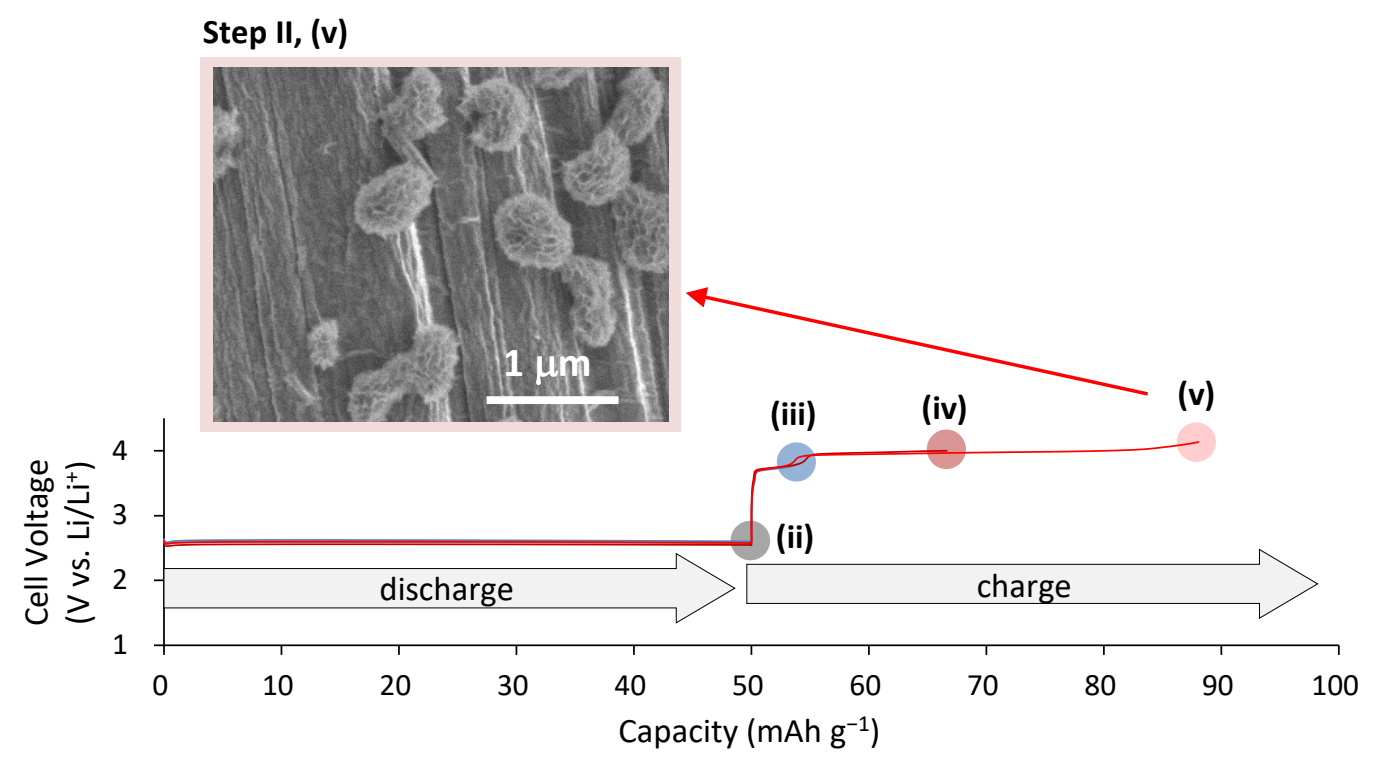

Figure S11. Galvanostatic discharge and charge curves of $\mathrm{Li}-\mathrm{O}_{2}$ batteries employing the MeCN-DMSO (1:1, v/v) of electrolyte and a SEM image of cathode obtained at (v) in step II. A scale bar, $1 \mu \mathrm{m}$.

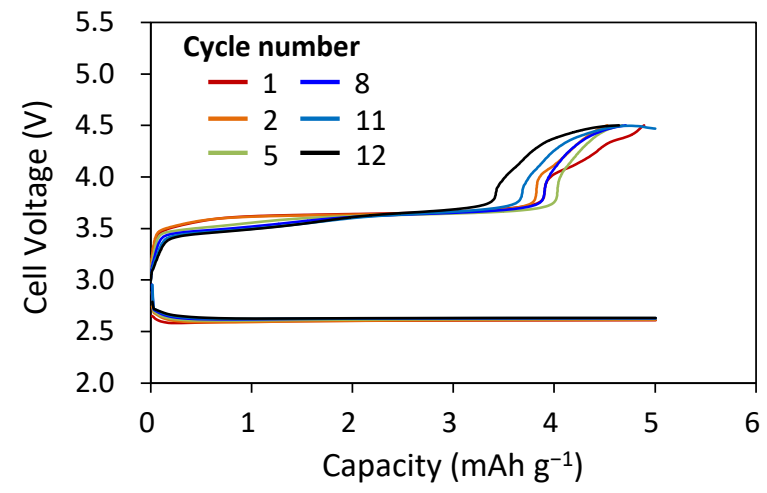

Figure S12. Discharge and charge curves of $\mathrm{Li}-\mathrm{O}_{2}$ batteries employing MeCN-DMSO $(1: 1, \mathrm{v} / \mathrm{v})$ of electrolyte. The applied current densities were $0.2 \mathrm{~mA} \mathrm{~cm}^{-1}$ and $0.02 \mathrm{~mA} \mathrm{~cm}{ }^{-1}$ for discharge and charge, respectively, and discharge capacities were limited to $5 \mathrm{mAh} \mathrm{g}^{-1}$. 
Table S1. Parameters used for calculation of $D_{\mathrm{Li}}$

\begin{tabular}{ccccc}
\hline electrolyte & $\begin{array}{c}\text { discharge } \\
\text { capacity (mAh) }\end{array}$ & $m / M(\mathrm{~mol})$ & $V_{\mathrm{M} \text { for } \mathrm{Li}_{2} \mathrm{O}_{2}\left(\mathrm{~cm}^{3} \mathrm{~mol}^{-1}\right)}$ & $S^{*}\left(\mathrm{~cm}^{2}\right)$ \\
\hline DMSO & 1.285 & $2.397 \times 10^{-5}$ & 38.03 & 79.67 \\
$\begin{array}{c}\mathrm{MeCN}-\mathrm{DMSO} \\
(1: 1, \mathrm{v} / \mathrm{v})\end{array}$ & 1.280 & $2.388 \times 10^{-5}$ & 38.03 & 79.36 \\
\hline
\end{tabular}

* The specific surface areas of cathode were $0.31 \pm 0.20 \mathrm{~m}^{2}$ BET $\mathrm{g}^{-1}$ which were measured by $\mathrm{Kr}$ (99.999\%) physisorption with a BELSOAP-MAX (MicrotracBEL) at $77 \mathrm{~K}$ employing the Brunauer-Emmett-Teller isotherm. 
Table S2. Crystal structure parameters of (i), (ii), (iii), and (iv), determined by Rietveld analyses

\begin{tabular}{|c|c|c|c|c|c|c|c|c|}
\hline Sample & $\begin{array}{c}\text { Phase } \\
\text { (Space group) }\end{array}$ & Atom & $\begin{array}{l}\text { Wyckoff } \\
\text { position }\end{array}$ & $g$ & $x$ & $y$ & $z$ & $B^{*} / \AA^{2}$ \\
\hline \multirow[t]{5}{*}{ (i) } & $\mathrm{Li}_{2-x} \mathrm{O}_{2}$ & Li1 & $2 a$ & $0.68(1)$ & 0 & 0 & 0 & 1 \\
\hline & $\left(P 6_{3} / m m c\right)$ & Li2 & $2 c$ & 1 & $1 / 3$ & $2 / 3$ & $1 / 4$ & 1 \\
\hline & & $\mathrm{O} 1$ & $4 f$ & 1 & $1 / 3$ & $2 / 3$ & $0.649(1)$ & 0.8 \\
\hline & $a_{\mathrm{h}}=3.1398(1)$ & and $c_{\mathrm{h}}=$ & $7.619(1) \AA$ & & & & & \\
\hline & Reliability fact & $\mathrm{s}: R_{\mathrm{wp}}=$ & $88 \%, R_{\mathrm{p}}=$ & $0.49 \%$, a & $=0.5$ & & & \\
\hline \multirow[t]{5}{*}{ (ii) } & $\mathrm{Li}_{2-x} \mathrm{O}_{2}$ & Li1 & $2 a$ & $0.70(1)$ & 0 & 0 & 0 & 1 \\
\hline & $\left(P 6_{3} / m m c\right)$ & $\mathrm{Li} 2$ & $2 c$ & 1 & $1 / 3$ & $2 / 3$ & $1 / 4$ & 1 \\
\hline & & $\mathrm{O} 1$ & $4 f$ & 1 & $1 / 3$ & $2 / 3$ & $0.650(1)$ & 0.8 \\
\hline & $a_{\mathrm{h}}=3.1394(1)$ & and $c_{\mathrm{h}}=$ & $7.6189(8) A$ & & & & & \\
\hline & Reliability fact & $\mathrm{s}: R_{\mathrm{wp}}=$ & $86 \%, R_{\mathrm{p}}=$ & $0.50 \%$, a & $=0.5$ & & & \\
\hline \multirow[t]{6}{*}{ (iii) } & $\mathrm{Li}_{2-x} \mathrm{O}_{2}$ & Li1 & $2 a$ & $0.76(1)$ & 0 & 0 & 0 & 1 \\
\hline & $\left(\mathrm{Pb}_{3} / \mathrm{mmc}\right)$ & Li2 & $2 c$ & 1 & $1 / 3$ & $2 / 3$ & $1 / 4$ & 1 \\
\hline & & $\mathrm{O} 1$ & $4 f$ & 1 & $1 / 3$ & $2 / 3$ & $0.650(1)$ & 0.8 \\
\hline & $a_{\mathrm{h}}=3.1416(1)$ & and $c_{\mathrm{h}}=$ & $7.628(1) \AA$ & & & & & \\
\hline & Mass fractions: & $9.6 \% \mathrm{f}$ & $\mathrm{Li}_{2-x} \mathrm{O}_{2}$ an & $20.4 \% \mathrm{f}$ & $\mathrm{OH}$. & & & \\
\hline & Reliability fact & $\mathrm{s}: R_{\mathrm{wp}}=$ & $.79 \%, R_{\mathrm{p}}=$ & $0.47 \%$, a & $=0.5$ & & & \\
\hline \multirow[t]{6}{*}{ (iv) } & $\mathrm{Li}_{2-x} \mathrm{O}_{2}$ & Li1 & $2 a$ & $0.60(2)$ & 0 & 0 & 0 & 1 \\
\hline & $\left(P 6_{3} / m m c\right)$ & $\mathrm{Li} 2$ & $2 c$ & 1 & $1 / 3$ & $2 / 3$ & $1 / 4$ & 1 \\
\hline & & $\mathrm{O} 1$ & $4 f$ & 1 & $1 / 3$ & $2 / 3$ & $0.650(1)$ & 0.8 \\
\hline & \multicolumn{8}{|c|}{$a_{\mathrm{h}}=3.1406(1) \AA$ and $c_{\mathrm{h}}=7.625(1) \AA$} \\
\hline & \multicolumn{8}{|c|}{ Mass fractions: $88.2 \%$ for $\mathrm{Li}_{2-x} \mathrm{O}_{2}$ and $11.8 \%$ for $\mathrm{LiOH}$. } \\
\hline & \multicolumn{8}{|c|}{ Reliability factors: $R_{\mathrm{wp}}=0.69 \%, R_{\mathrm{p}}=0.39 \%$, and $S=0.42$. } \\
\hline
\end{tabular}

$* B(\mathrm{Li} 1)$ and $B(\mathrm{Li} 2)$ are fixed as 1 , whereas $B(\mathrm{O} 1)$ is fixed as 0.8 . 